\title{
Molecular Docking Performance of Selective Organic Compounds with Target Protein
}

\author{
Jacquline Rosy Pushparaj 1(D), Murugan Moorthiraman 1(D), Bharanidharan Sarangapani 2(D), \\ Rajamohan Rajaram ${ }^{3, *(D)}$ \\ 1 Department of Chemistry, IFET College of Engineering (Autonomous), Villupuram - 605 108, Tamil Nadu, India; \\ jacquline.rosy@yahoo.com (J.R), m_murugan79@rediffmail.com (M.M); \\ 2 Department of Physics, PRIST University, Puducherry Campus - 605 007, Puducherry, India; \\ bharani.dharan0@gmail.com (B.S); \\ 3 Department of Chemistry, PRIST University, Puducherry Campus - 605 007, Puducherry, India; \\ mohanakp81@ rediffmail.com (R.R); \\ * Correspondence: mohanakp81@ rediffmail.com;
}

Received: 7.12.2020; Revised: 1.01.2021; Accepted: 2.01.2021; Published: 4.01.2021

\begin{abstract}
In this article, the docking analysis has been carried out to know some selective compounds' interaction to bind with a targeted protein. There are three approaches have been analyzed here with three different kinds of protein as the target species. They are 2-aminobenzimidazole (2ABZ) with Acetylcholinesterase receptor (AChE), Phenoxazine (POZ) with Penicillin-binding proteins (PBPs) receptor, and Phenothiazines with Calcium/calmodulin-dependent protein kinase IV (CAMK IV) receptor. All three studies showed that the binding is perfect at the binding site and explained with hydrogen bonding interaction via donor-acceptor interactions.
\end{abstract}

Keywords: organic compounds; AChE; PBPs; CAMKIV; molecular docking.

(C) 2020 by the authors. This article is an open-access article distributed under the terms and conditions of the Creative Commons Attribution (CC BY) license (https://creativecommons.org/licenses/by/4.0/).

\section{Introduction}

In recent days, the computational approaches that 'dock' small molecules into the inner cavity and structures of macromolecular targets and 'score' their expected complementarity towards the binding sites are generally utilized in hit identification and lead optimization. To be sure, there are presently various drugs whose development was intensively influenced by or dependent on the structure-based design and screening techniques, for example, HIV protease inhibitors [1-6]. All things considered, there are considerable difficulties in the application of these approaches, precisely according to current scoring schemes. On a fundamental level, the docking process involves predicting the ligand conformation and orientation (or posing) inside a focused on a targeted binding site. In general, there are two significant aims of docking studies. The first one is accurate structural modeling, and the other one is the correct prediction of activity. However, the identification of molecular features that are responsible for specific biological recognition and its applications, or the prediction for the modifications/alteration of a compound that may be used to enhance ability, mostly creates complex issues that are frequently very tough and hard to understand easily and frequently [7].

Computational approaches have the potential to speed up the drug discovery process, thus reducing the costs and changing the way drugs are designed and formulated. Rational Drug Design (RDD) facilitates and speeds up the drug designing process, involving a variety of 
methods to identify novel compounds [8-17]. One such method is the docking of the drug molecule with the receptor (target). The site of drug action, which is ultimately responsible for the pharmaceutical effect, is a receptor. Docking is the process by which two molecules fit together in 3D space.

Generally, plenty of inhibitors are available to study the binding ability with the targeted proteins [18-19]. Acetylcholinesterase (AChE), Penicillin-binding proteins (PBPs), and Calcium/calmodulin-dependent protein kinase type IV are the main and common receptors to study the binding interactions with the drugs or organic molecules. Acetylcholinesterase (AChE) is a key inhibitor involved in the termination of nerve signals through acetylcholine hydrolysis. It targets drug development to combat neuromuscular disorders such as myasthenia gravis, glaucoma, and Alzheimer's disease (AD) [20]. AChE is found in many types of conducting tissue: nerve and muscle, central and peripheral tissues, motor and sensory fibers, and cholinergic and noncholinergic fibers. The activity of AChE is higher in motor neurons than in sensory neurons [21-23]. AChE is also found on the red blood cell membranes, where different forms constitute the Yt blood group antigens [24]. AChE exists in multiple molecular forms, which possess similar catalytic properties but differ in their oligomeric assembly and attachment mode to the cell surface.

Penicillin-binding proteins (PBPs) are a group of proteins characterized by their affinity for and binding penicillin. They are a normal constituent of many bacteria; the name just reflects how the protein was discovered.

Calcium/calmodulin-dependent protein kinase type IV is an enzyme that in humans is encoded by the CAMK4 gene [25]. In biology, a gene is a sequence of nucleotides in DNA or RNA that encodes a gene product's synthesis, either RNA or protein. This gene's product belongs to the serine/threonine-protein kinase family and the $\mathrm{Ca}^{2+} /$ calmodulin-dependent protein kinase (CAMK) subfamily. This enzyme is a multifunctional serine/threonine-protein kinase with limited tissue distribution that has been implicated in transcriptional regulation in lymphocytes, neurons, and male germ cells [25].

Benzimidazole and its derivatives are regarded as important heterocyclic molecules that exhibit a wide range of pharmaceutical applications, including anti-microbial, anti-cancer, antihypertensive, anti-viral, anti-fungal, anti-HIV, anti-convulsant, and anti-diabetic. Given their wide-ranging activities and importance in the biological applications as novel compounds, the synthesis of benzimidazoles and their derivatives remains a primary goal for any synthetic chemistry communities [26].

Phenoxazine and its derivatives like phenothiazine compounds are the most important compounds in the class of nitrogen-oxygen heterocyclic compounds that are widely used as dyes and pigments [27]. We have to find to exhibit a broad spectrum of pharmacological activity such as CNS depressant, sedatives, antiepileptics, herbicidal, tranquilizers, antituberculosis, antitumor, antibacterial, spasmolytic, anthelminthic, and parasitical effects [28]. Phenothiazines belong to the oldest, synthetic antipsychotic drugs, which do not have their precursor in the world of natural compounds.

According to literature referenced data on relations between chemical structures of 2ABZ, PTZ, POZ, and their biological orientation, the main directions for molecular modeling studies can be carried out.

Therefore, docking is very useful for finding both the strength and type of signal produced during the process. In a structure-based drug design, molecular docking is one of the 
most frequently used methods because of its ability to predict small-molecule ligands' bindingconformation to the appropriate target binding site.

\section{Molecular Modeling}

The objective of the study is to demonstrate that 2ABZ, PTZ, and POZ bind to Acetylcholinesterase Receptor (AChE), Penicillin-binding proteins (PBPs), and Calcium/calmodulin-dependent protein kinase IV (CAMK IV) Receptor enzyme (Figure 1), respectively and to evaluate whether these molecules can be used as a potential drug. The structural information and relevant data for the target were collected from the "Protein Data Bank" (PDB). The PDB ID: 1CEF [29], and PDB ID: 2W40 [30] were used as the template for our studies.

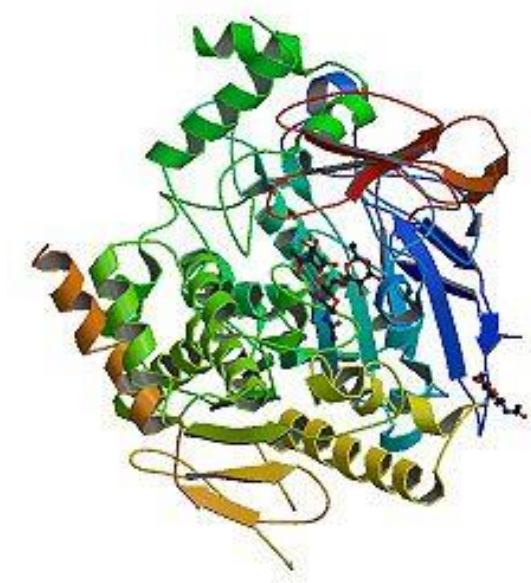

(a)

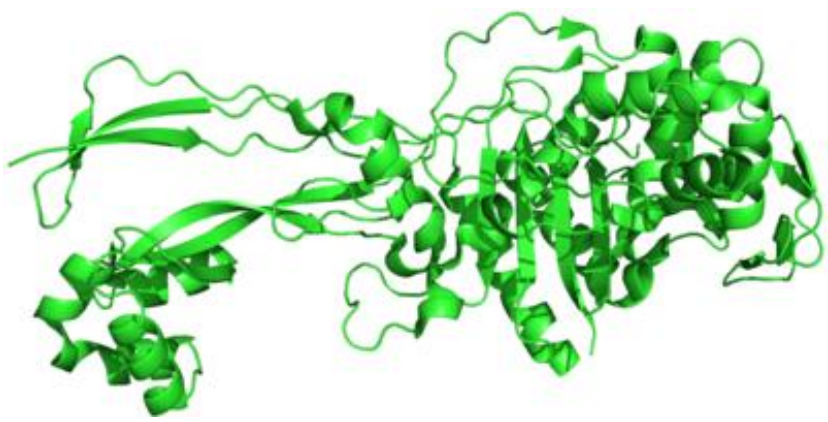

(b)<smiles>Nc1nc2ccccc2[nH]1</smiles>

(c)

(d)

(e)

Figure 1. The structure of (a) Acetylcholinesterase (AChE) Receptor; (b) Penicillin binding proteins (PBPs) receptor; (c) 2-aminobenzimidazole (2ABZ); (d) Phenothiazine (PTZ); (e) Phenoxazine (POZ).

Calcium/calmodulin-dependent protein kinase IV (CAMKIV) is also one of the important receptors associated with many diseases, including cancer, neurodegenerative disorders, and so on. Thus, the receptor is being considered as a potential drug target.

In this study, molecular docking was performed using Auto-Dock software to predict the interaction mode and selectivity of the chosen molecules for AChE. Auto-Dock 4.2.0 was employed to perform the docking calculations [31]. Generate a grid box size of 20, 22, $24 \AA^{3}$ points was used, centered on the mass center of the crystallographic macromolecule encompassing all active-site atoms. 
X-ray crystal structures of the TcAChE in complex with donepezil (PDB: 1EVE) was selected to build the starting model of AChE [32]. 2ABZ compound was chosen for molecular modeling as the most active compound of AChE inhibitor.

\section{Results and Discussion}

3.1. Molecular docking studies of 2-aminobenzimidazole with Acetylcholinesterase Receptor as the target protein.

The dock, glide energy, and hydrogen bonding interactions of the 2ABZ and cocrystallized ligand are given in Table 1 . A view of the X-ray crystal structure of the $2 \mathrm{ABZ}$ in the AChE receptor active site showing the key hydrogen contacts between inhibitor and enzyme is depicted in Figure 2. The co-crystallized ligand in the AChE receptor active site showing the key hydrogen contacts between inhibitor and enzyme is depicted in Figure 3. The surface diagram showing the $2 \mathrm{ABZ}$ docked at the active site of the AChE receptor is depicted in Figure 4.

X-ray crystal structures confirmed the expected binding mode. Considering binding orientation and electronic properties enabled optimization to $2 \mathrm{ABZ}$ as a more potent secondgeneration lead.

Molecular docking studies are based on the fact that $2 \mathrm{ABZ}$ is an antibacterial drug, and it is proved to exert its action by the inhibition of $\mathrm{AChE}$ in trails. Based on the drug action, it has been performed docking simulation of the $2 \mathrm{ABZ}$ binding the AChE crystal structure's active site.

The docking result of the $2 \mathrm{ABZ}$ showed high binding energy with AChE targeted protein. $2 \mathrm{ABZ}$ showed excellent binding energy and compared co-crystal ligand with -6.8 and $6.6 \mathrm{kcal} / \mathrm{mol}$, respectively for AChE enzyme. The binding energies and residues involved in $\mathrm{H}$-bonding are tabulated in Table 1.

Table 1. Hydrogen bond interactions of $2 \mathrm{ABZ}$ with amino acids at the active site of AChE receptor.

\begin{tabular}{|c|c|c|c|c|}
\hline \multirow{2}{*}{ Compound } & \multirow{2}{*}{$\begin{array}{c}\text { Docking Score } \\
\text { (kcal/mol) }\end{array}$} & \multicolumn{3}{|c|}{ Hydrogen Bonding Interactions } \\
\hline & & Donor & Acceptor & Distance $(\AA)$ \\
\hline \multirow{3}{*}{$2 \mathrm{ABZ}$} & \multirow{3}{*}{-6.8} & $\mathrm{~N}$ [SER80] & $\mathrm{N}^{*}$ & 2.9 \\
\hline & & O [ASP71] & $\mathrm{O}^{*}$ & 3.1 \\
\hline & & O [TYR333] & $\mathrm{O}^{*}$ & 2.9 \\
\hline Co-Crystal & -6.6 & O [ASP71] & $\mathrm{O}-\mathrm{H}^{*}$ & 3.3 \\
\hline
\end{tabular}

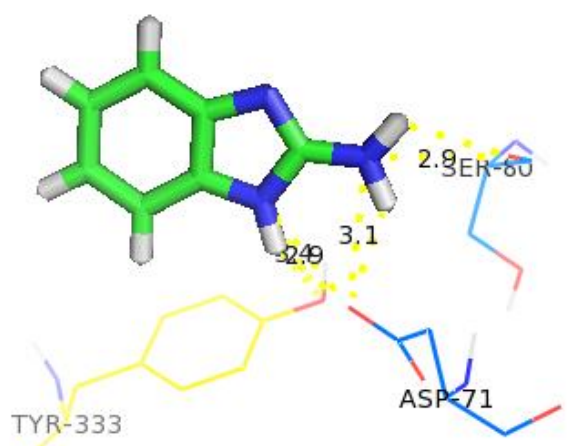

Figure 2. The $2 \mathrm{ABZ}$ in the $\mathrm{AChE}$ receptor active site showing the key hydrogen contacts between the 2ABZ inhibitor and enzyme. 


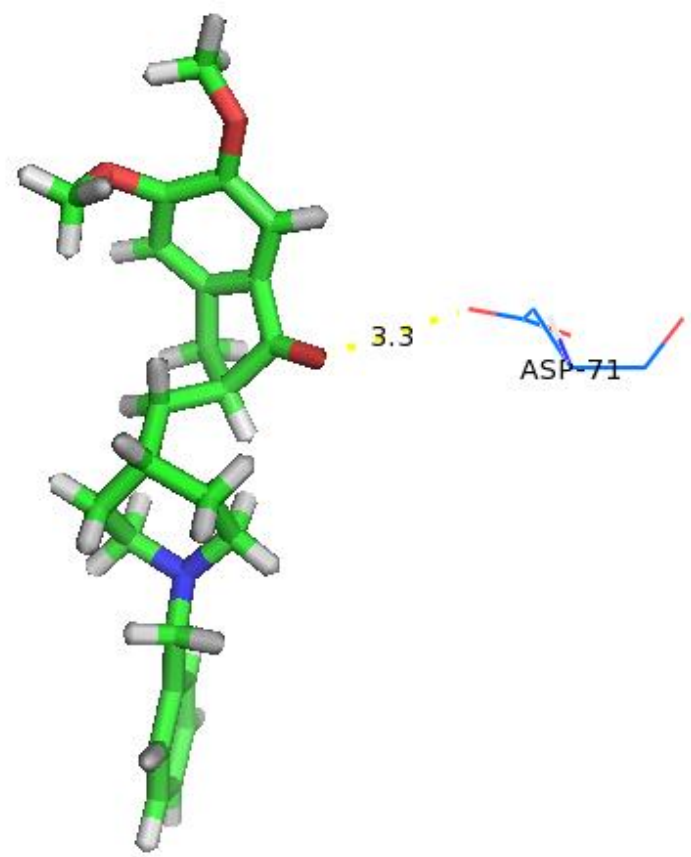

Figure 3. The co-crystallized ligand (dexamethasone) in the AChE receptor active site showing the key hydrogen contacts between inhibitor and enzyme.

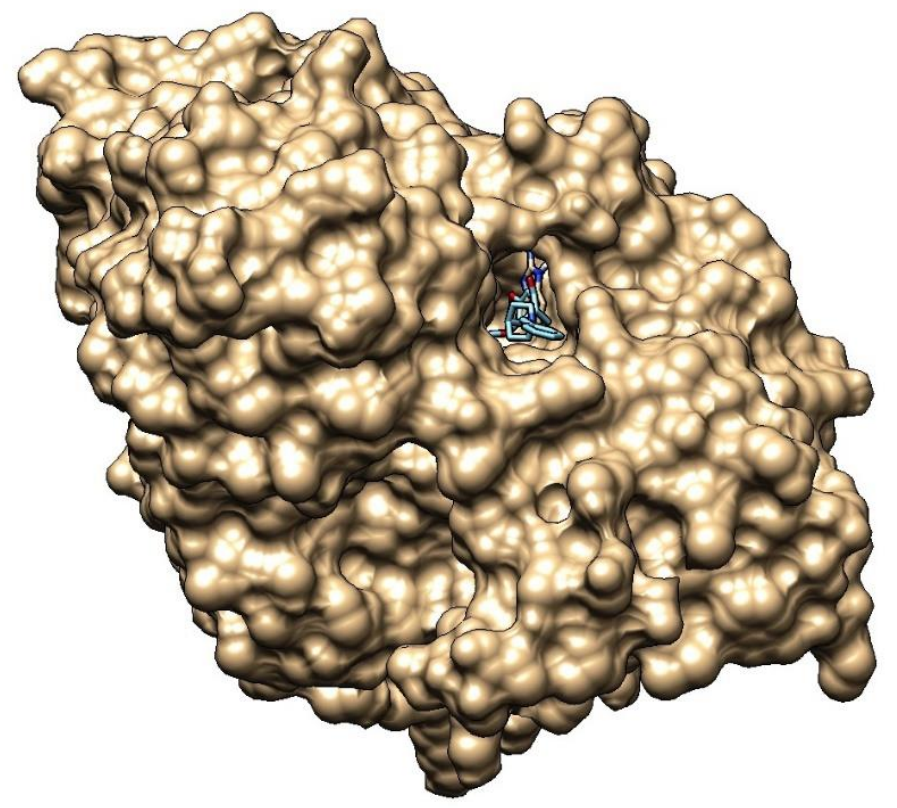

Figure 4. Surface diagram showing the $2 \mathrm{ABZ}$ docked at the active site of AChE receptor.

3.2. Molecular docking studies of Phenoxazine (POZ) with Penicillin-binding proteins (PBPs) receptor as the target protein.

The dock, glide energy, and hydrogen bonding interactions of the POZ and its cocrystallized ligand are provided in Table 2 . A view of the X-ray crystal structure of the POZ in the PBPs receptor active site showing the key hydrogen contacts between inhibitor and enzyme is depicted in Figure 5. The co-crystallized ligand in the PBPs receptor active site showing the key hydrogen contacts between inhibitor and enzyme is depicted in Figure 6. The surface diagram showing the title compound docked at the PBPs receptor's active site is depicted in Figure 7. 
X-ray crystal structures confirmed the expected binding mode. Considering binding orientation and electronic properties enabled optimization to POZ as a more potent secondgeneration lead.

The POZ is shown to be an effective inhibitor. The amide group in the THR301 interacts with the carbonyl group's oxygen atom at a distance of $3.1 \AA$. The co-crystallized ligand also docked well, and it shows better interactions with residues THR299, SER62, THR301, ASN161, and THR116, respectively [33-37]. The results show that the POZ has better binding energy, and the co-crystallized ligand has comparable interactions.

Table 2. Hydrogen bond interactions of POZ with amino acids at the active site of PBPs receptor.

\begin{tabular}{|c|c|c|c|c|}
\hline \multirow{2}{*}{ Compound } & \multirow{2}{*}{$\begin{array}{c}\text { Docking } \\
\text { Score }\end{array}$} & \multicolumn{3}{|c|}{ Hydrogen Bonding Interactions } \\
\hline & & Donor & Acceptor & Distance (̊̊) \\
\hline $\mathrm{POZ}$ & -6.1 & O [THR301] & $\mathrm{N}-\mathrm{H}^{*}$ & 3.4 \\
\hline \multirow{6}{*}{ Co-Crystal } & \multirow{6}{*}{-6.6} & O [THR299] & $\mathrm{N}-\mathrm{H}^{*}$ & 3.0 \\
\hline & & O [SER62] & $\mathrm{N}-\mathrm{H}^{*}$ & 3.3 \\
\hline & & O [THR301] & $\mathrm{N}-\mathrm{H}^{*}$ & 3.3 \\
\hline & & O-H [ASN161] & $\mathrm{O}^{*}$ & 3.5 \\
\hline & & O-H [THR116] & O* & 3.5 \\
\hline & & * Ligand & & \\
\hline
\end{tabular}

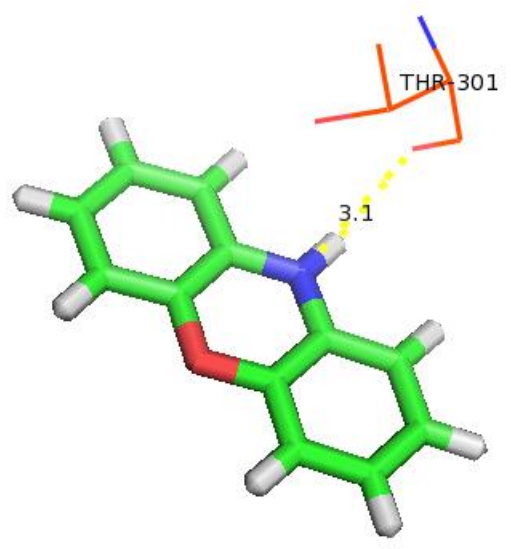

Figure 5. The POZ in the PBPs receptor active site showing the key hydrogen contacts between POZ inhibitor and enzyme.

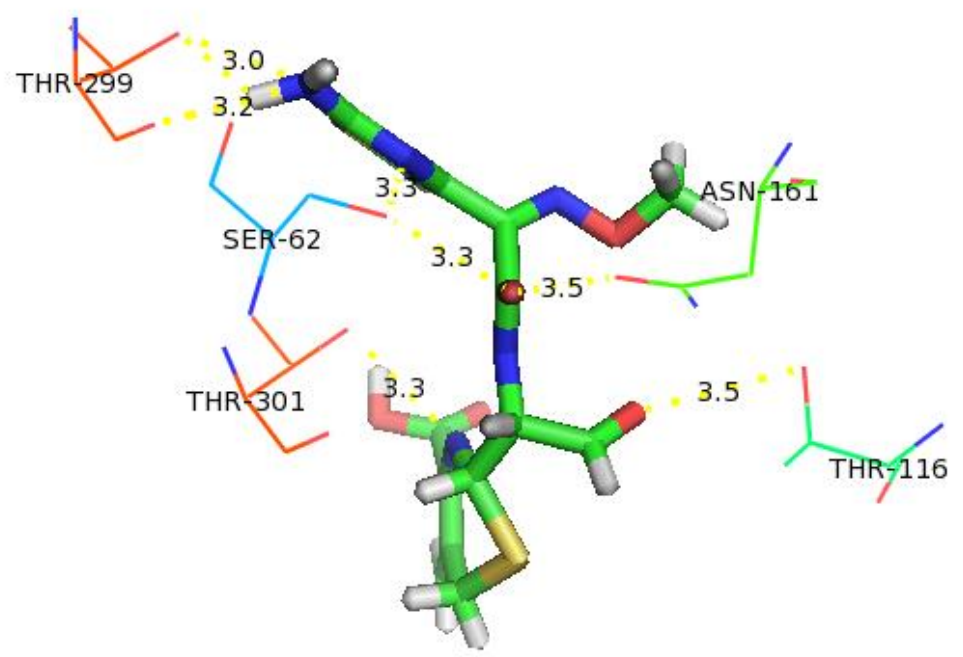

Figure 6. The co-crystallized ligand (dexamethasone) in the PBPs receptor active site showing the key hydrogen contacts between inhibitor and enzyme. 


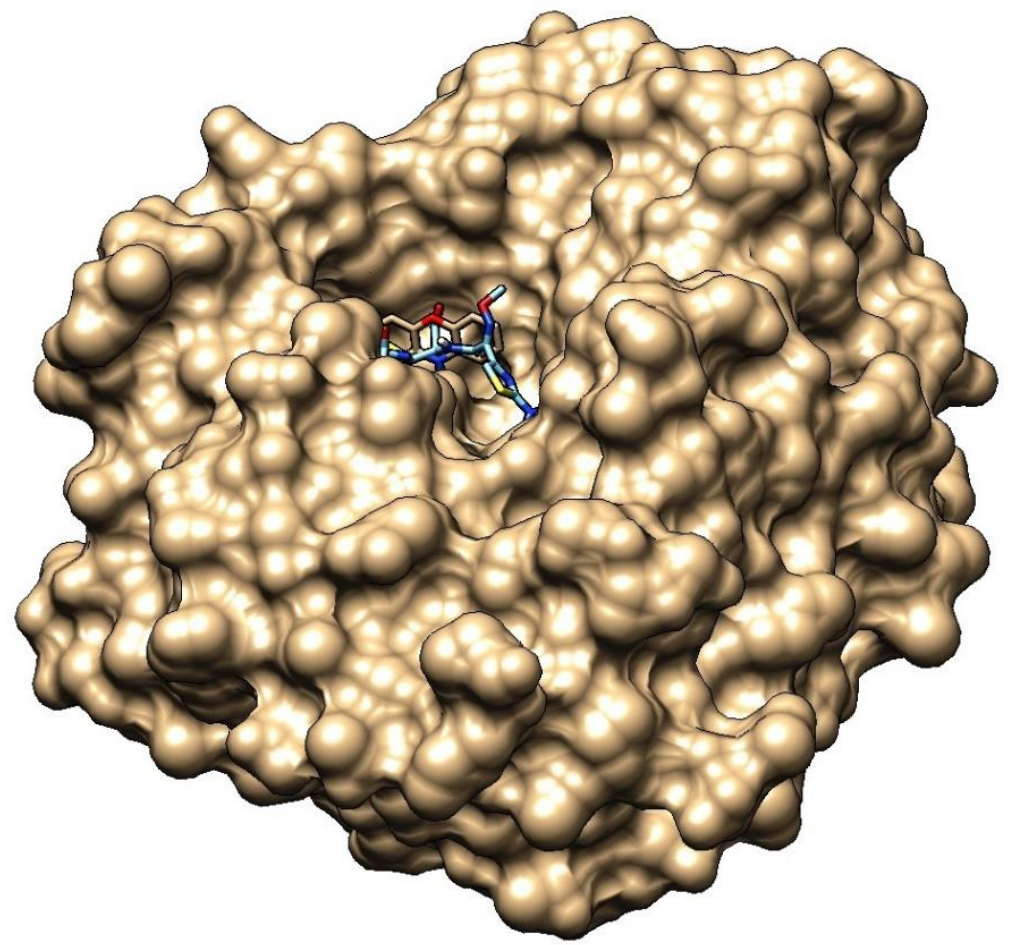

Figure 7. Surface diagram showing the POZ docked at the active site of PBPs receptor.

3.3. Molecular docking studies of Phenothiazines with Calcium/calmodulin-dependent protein kinase IV (CAMK IV) Receptor as the target protein.

The dock, glide energy, and hydrogen bonding interactions of the PTZ compound and co-crystallized ligand are given in Table 3. A view of the X-ray crystal structure of the PTZ in the CAMK IV Receptor active site showing the key hydrogen contacts between inhibitor and enzyme is depicted in Figure 8. The surface diagram showing the PTZ compound docked at the CAMK IV Receptor's active site is depicted in Figure 9.

Table 3. Hydrogen bond interactions of PTZ with amino acids at the active site of CAMK IV Receptor.

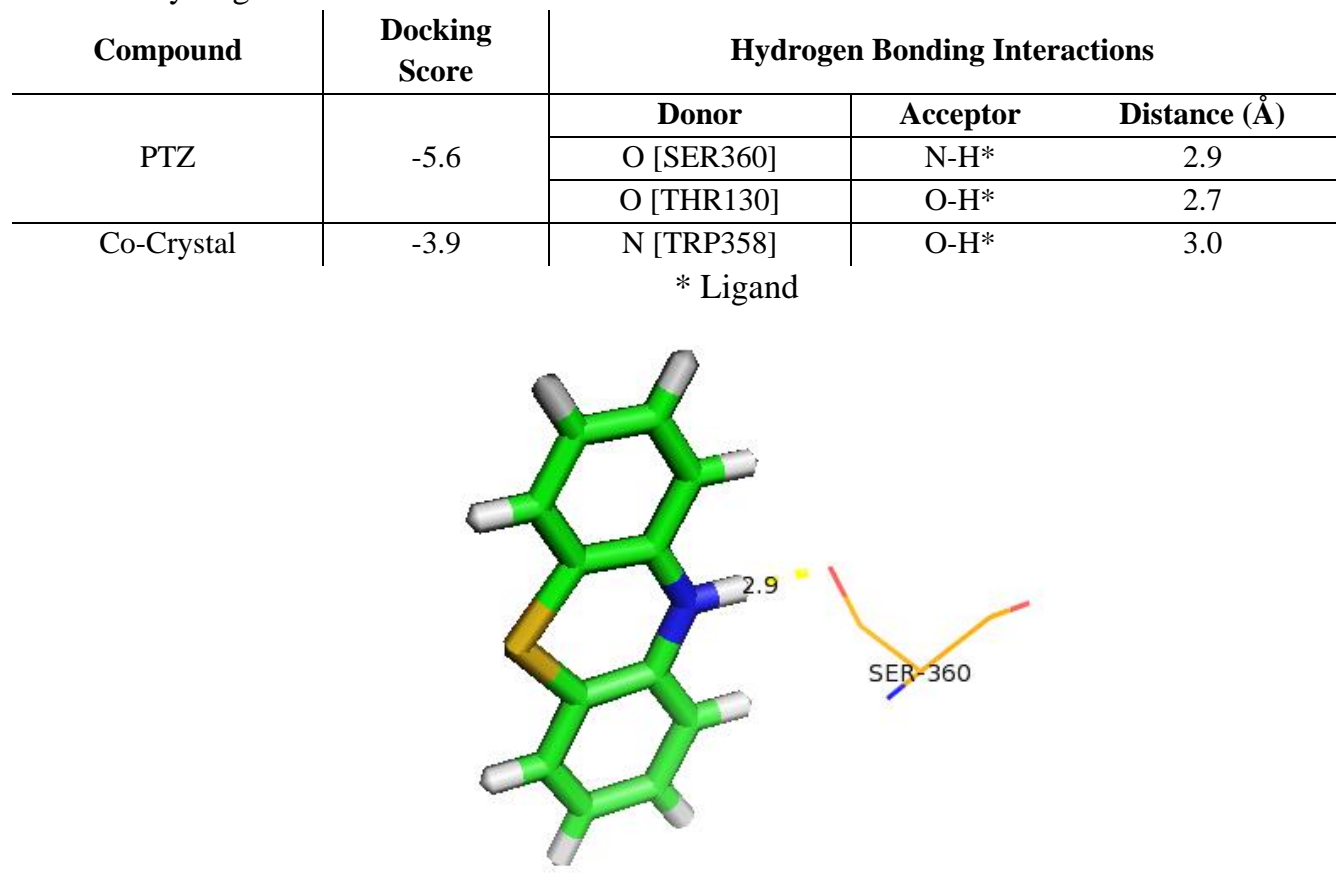

Figure 8. The PTZ in the CAMK IV Receptor active site showing the key hydrogen contacts between PTZ inhibitor and enzyme. 
X-ray crystal structures confirmed the expected binding mode. Considering binding orientation and electronic properties enabled optimization to PTZ as a more potent secondgeneration lead.

The PTZ is shown to be an effective inhibitor. The amide group in the SER360 interacts with the carbonyl group's oxygen atom at a distance of $2.9 \AA$. The co-crystallized ligand also docked well, and it shows better interactions. The results show that the PTZ has better binding energy, and the co-crystallized ligand has comparable interactions.

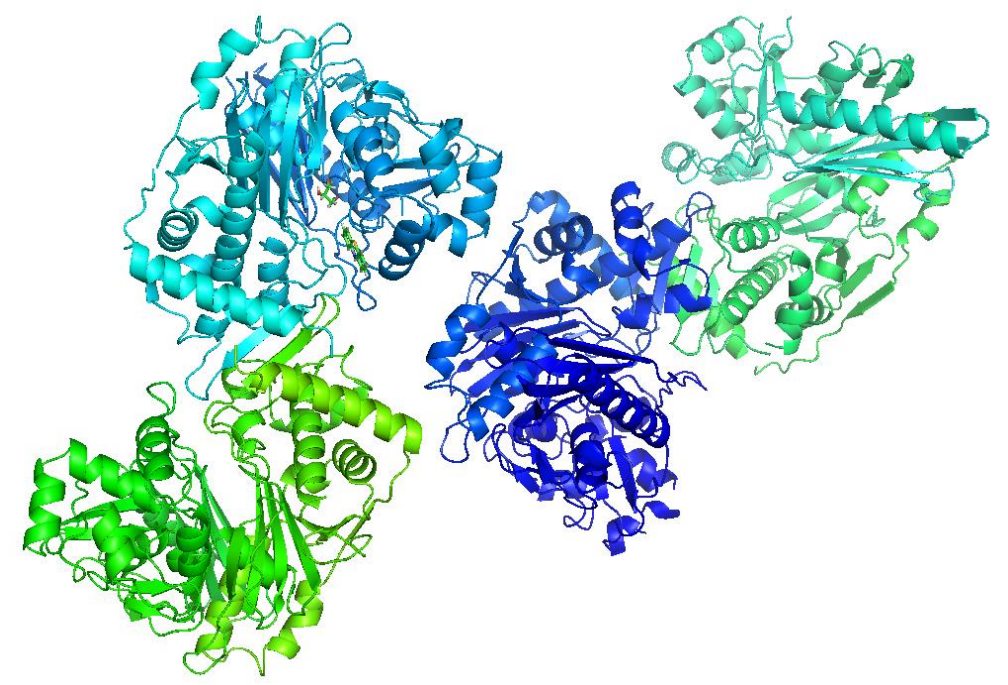

Figure 9. Cartoon diagram showing the PTZ docked at the active site of CAMK IV Receptor.

\section{Conclusions}

In this study, three chemically synthesized compounds were screened to find a new drug design by using the SBDD approach. These three different inhibitors were subjected to structure-based drug design (SBDD) to observe the docking score and hydrogen bond interactions. The active site of 2-aminobenzimidazole binds with Acetylcholinesterase Receptor, Phenoxazine (POZ) bind with Penicillin Penicillin-binding proteins (PBPs), and Phenothiazines bind with Calcium/calmodulin-dependent protein kinase IV (CAMK IV) Receptor as the target protein. These inhibitors were compared with re-docked complex protein using docking score, hydrogen bond and hydrophobic interactions, and binding free energy. All the SBDD have better docking scores and showed good binding free energy. Hydrogen and hydrophobic interactions were analyzed and revealed that having exhibited favorable interactions with the active site residues. The potential inhibition of SBDD could be revealed through in-vivo and in-vitro studies. It may be used to a new design of drugs against the targetted protein.

Funding: This research received no external funding.

\section{Acknowledgments}

The authors acknowledge the IFET College of Engineering, Villupuram, and PRIST University, Puducherry Campus, for technical support.

\section{Conflicts of Interest}

The authors declare no conflict of interest. 


\section{References}

1. Romeo, A.; Iacovelli, F.; Falconi, M. Targeting the SARS-CoV-2 spike glycoprotein prefusion conformation: virtual screening and molecular dynamics simulations applied to the identification of potential fusion inhibitors. Virus Res. 2020, 286, 198068, https://doi.org/10.1016/j.virusres.2020.198068.

2. Kalathiya, U.; Padariya, M.; Mayordomo, M.; Lisowska, M.; Nicholson, J.; Singh, A.; Baginski, M.; Fahraeus, R.; Carragher, N.; Ball, K. Highly Conserved Homotrimer Cavity Formed by the SARS-CoV-2 Spike Glycoprotein: A Novel Binding Site. Journal of Clinical Medicine 2020, 9, 1473, https://doi.org/10.3390/jcm9051473.

3. Yang, C.; Ke, C.; Yue, D.; Li, W.; Hu, Z.; Liu, W.; Hu, S.; Wang, S.; Liu, J. Effectiveness of Arbidol for COVID-19 Prevention in Health Professionals. Frontiers in Public Health 2020, 8, 249, https://doi.org/10.3389/fpubh.2020.00249.

4. Yao, X.; Ye, F.; Zhang, M.; Cui, C.; Huang, B.; Niu, P.; Liu, X.; Zhao, L.; Dong, E.; Song, C.; Zhan, S.; Lu, R.; Li, H.; Tan, W.; Liu, D. In Vitro Antiviral Activity and Projection of Optimized Dosing Design of Hydroxychloroquine for the Treatment of Severe Acute Respiratory Syndrome Coronavirus 2 (SARS-CoV2). Clin. Infect. Dis. 2020, 71, 732-739, https://doi.org/10.1093/cid/ciaa237.

5. Yu, B.; Li, C.; Chen, P.; Zhou, N.; Wang, L.; Li, J.; Jiang, H.; Wang, D.-W. Low dose of hydroxychloroquine reduces fatality of critically ill patients with COVID-19. Science China Life Sciences 2020, 63, 1515-1521, https://doi.org/10.1007/s11427-020-1732-2.

6. Gautret, P.; Lagier, J.-C.; Parola, P.; Hoang, V.T.; Meddeb, L.; Mailhe, M.; Doudier, B.; Courjon, J.; Giordanengo, V.; Vieira, V.E.; Tissot Dupont, H.; Honoré, S.; Colson, P.; Chabrière, E.; La Scola, B.; Rolain, J.-M.; Brouqui, P.; Raoult, D. Hydroxychloroquine and azithromycin as a treatment of COVID-19: results of an open-label non-randomized clinical trial. Int. J. Antimicrob. Agents 2020, 56, 105949, https://doi.org/10.1016/j.ijantimicag.2020.105949.

7. Kitchen, D.B.; Decornez, H.; Furr, J.R.; Bajorath, J. Docking and scoring in virtual screening for drug discovery: methods and applications. Nature Reviews Drug Discovery 2004, 3, 935-949, https://doi.org/10.1038/nrd1549.

8. Christensen, J.G.; Zou, H.Y.; Arango, M.E.; Li, Q.; Lee, J.H.; McDonnell, S.R.; Yamazaki, S.; Alton, G.R.; Mroczkowski, B.; Los, G. Cytoreductive antitumor activity of PF-2341066, a novel inhibitor of anaplastic lymphoma kinase and c-Met, in experimental models of anaplastic large-cell lymphoma. Mol. Cancer Ther. 2007, 6, 3314, https://doi.org/10.1158/1535-7163.MCT-07-0365.

9. Leite, T.B.; Gomes, D.; Miteva, M.A.; Chomilier, J.; Villoutreix, B.O.; Tufféry, P. Frog: a FRee Online druG 3D conformation generator. Nucleic Acids Res. 2007, 35, W568-W572, https://doi.org/10.1093/nar/gkm289.

10. Wang, X.; Cao, R.; Zhang, H.; Liu, J.; Xu, M.; Hu, H.; Li, Y.; Zhao, L.; Li, W.; Sun, X.; Yang, X.; Shi, Z.; Deng, F.; Hu, Z.; Zhong, W.; Wang, M. The anti-influenza virus drug, arbidol is an efficient inhibitor of SARS-CoV-2 in vitro. Cell Discovery 2020, 6, 28, https://doi.org/10.1038/s41421-020-0169-8.

11. Vankadari, N. Arbidol: A potential antiviral drug for the treatment of SARS-CoV-2 by blocking trimerization of the spike glycoprotein. Int. J. Antimicrob. Agents 2020, 56, 105998, https://doi.org/10.1016/j.ijantimicag.2020.105998.

12. Fan, H.-H.; Wang, L.-Q.; Liu, W.-L.; An, X.-P.; Liu, Z.-D.; He, X.-Q.; Song, L.-H.; Tong, Y.-G. Repurposing of clinically approved drugs for treatment of coronavirus disease 2019 in a 2019-novel coronavirus-related coronavirus model. Chin. Med. J. 2020, 133, https://doi.org/10.1097/CM9.0000000000000797.

13. Hu, T.; Frieman, M.; Wolfram, J. Insights from nanomedicine into chloroquine efficacy against COVID-19. Nature Nanotechnology, 2020, 15, 247-249. DOI: 10.1038/s41565-020-0674- Hu, T.Y.; Frieman, M.; Wolfram, J. Insights from nanomedicine into chloroquine efficacy against COVID-19. Nature Nanotechnology 2020, 15, 247-249, https://doi.org/10.1038/s41565-020-0674-9.

14. Wang, M.; Cao, R.; Zhang, L.; Yang, X.; Liu, J.; Xu, M.; Shi, Z.; Hu, Z.; Zhong, W.; Xiao, G. Remdesivir and chloroquine effectively inhibit the recently emerged novel coronavirus (2019-nCoV) in vitro. Cell Res. 2020, 30, 269-271, https://doi.org/10.1038/s41422-020-0282-0.

15. Maisonnasse, P.; Guedj, J.; Contreras, V.; Behillil, S.; Solas, C.; Marlin, R.; Naninck, T.; Pizzorno, A.; Lemaitre, J.; Gonçalves, A.; Kahlaoui, N.; Terrier, O.; Fang, R.H.T.; Enouf, V.; Dereuddre-Bosquet, N.; Brisebarre, A.; Touret, F.; Chapon, C.; Hoen, B.; Lina, B.; Calatrava, M.R.; van der Werf, S.; de Lamballerie, $\mathrm{X}$; Le Grand, R. Hydroxychloroquine use against SARS-CoV-2 infection in non-human primates. Nature 2020, 585, 584-587, https://doi.org/10.1038/s41586-020-2558-4. 
16. Wu, C.; Liu, Y.; Yang, Y.; Zhang, P.; Zhong, W.; Wang, Y.; Wang, Q.; Xu, Y.; Li, M.; Li, X.; Zheng, M.; Chen, L.; Li, H. Analysis of therapeutic targets for SARS-CoV-2 and discovery of potential drugs by computational methods. Acta Pharmaceutica Sinica B 2020, $10, \quad 766-788$, https://doi.org/10.1016/j.apsb.2020.02.008.

17. Mahdian, S.; Ebrahim-Habibi, A.; Zarrabi, M. Drug repurposing using computational methods to identify therapeutic options for COVID-19. Journal of Diabetes \& Metabolic Disorders 2020, https://doi.org/10.1007/s40200-020-00546-9.

18. Disney, M.D. Targeting RNA with Small Molecules To Capture Opportunities at the Intersection of Chemistry, Biology, and Medicine. J. Am. Chem. Soc. 2019, 141, 6776-6790, https://doi.org/10.1021/jacs.8b13419.

19. Minuesa, G.; Albanese, S.K.; Xie, W.; Kazansky, Y.; Worroll, D.; Chow, A.; Schurer, A.; Park, S.-M.; Rotsides, C.Z.; Taggart, J.; Rizzi, A.; Naden, L.N.; Chou, T.; Gourkanti, S.; Cappel, D.; Passarelli, M.C.; Fairchild, L.; Adura, C.; Glickman, J.F.; Schulman, J.; Famulare, C.; Patel, M.; Eibl, J.K.; Ross, G.M.; Bhattacharya, S.; Tan, D.S.; Leslie, C.S.; Beuming, T.; Patel, D.J.; Goldgur, Y.; Chodera, J.D.; Kharas, M.G. Small-molecule targeting of MUSASHI RNA-binding activity in acute myeloid leukemia. Nature Communications 2019, 10, 2691, https://doi.org/10.1038/s41467-019-10523-3.

20. Barnard, E.A. Neuromuscular Transmission-Enzymatic Destruction of Acetylcholine. In The Peripheral ;Nervous System, Hubbard, J.I., Ed. Springer US: Boston, MA, 1974; 201-224, https://doi.org/10.1007/9781-4615-8699-9_9.

21. Massoulié, J.; Pezzementi, L.; Bon, S.; Krejci, E.; Vallette, F.-M. Molecular and cellular biology of cholinesterases. Prog. Neurobiol. 1993, 41, 31-91, https://doi.org/10.1016/0301-0082(93)90040-y.

22. Chacko, L.W.; Cerf, J.A. Histochemical localization of cholinesterase in the amphibian spinal cord and alterations following ventral root section. J. Anat. 1960, 94, 74.

23. Koelle, G.B. The histochemical localization of cholinesterases in the central nervous system of the rat. $J$. Comp. Neurol. 1954, 100, 211-235, https://doi.org/10.1002/cne.901000108.

24. Bartels, C.F.; Zelinski, T.; Lockridge, O. Mutation at codon 322 in the human acetylcholinesterase (ACHE) gene accounts for YT blood group polymorphism. Am. J. Hum. Genet. 1993, 52, 928-936.

25. Sikela, J.M.; Law, M.L.; Kao, F.-T.; Hartz, J.A.; Wei, Q.; Hahn, W.E. Chromosomal localization of the human gene for brain Ca2+calmodulin-dependent protein kinase type IV. Genomics 1989, 4, 21-27, https://doi.org/10.1016/0888-7543(89)90309-1.

26. Sreerama, R.; Barnali, M.; Balamurali, M.M.; Kaushik, C. Synthesis and Medicinal Applications of Benzimidazoles: An Overview. Current Organic Synthesis 2017, 14, 40-60, http://dx.doi.org/10.2174/1570179413666160818151932.

27. Pluta, K.; Morak-Młodawska, B.; Jeleń, M. Recent progress in biological activities of synthesized phenothiazines. Eur. J. Med. Chem. 2011, 46, 3179-3189, https://doi.org/10.1016/j.ejmech.2011.05.013.

28. Blank, B.; Baxter, L.L. Synthesis and antiinflammatory screening of phenoxazine-1-carboxylic acids. J. Med. Chem. 1968, 11, 807-811, https://doi.org/10.1021/jm00310a024.

29. Knox, J.R.; Kuzin, A.P. Cefotaxime complexed with the streptomyces r61 dd-peptidase, Protein Data Bank, 1996, https://doi.org/10.2210/pdb1cef/pdb.

30. Schnick, C.; Polley, S.D.; Fivelman, Q.L.; Ranford-Cartwright, L.C.; Wilkinson, S.R.; Brannigan, J.A.; Wilkinson, A.J.; Baker, D.A. Structure and non-essential function of glycerol kinase in Plasmodium falciparum blood stages. Mol. Microbiol. 2009, 71, 533-545, https://doi.org/10.1111/j.13652958.2008.06544.x.

31. Morris, G.M.; Goodsell, D.S.; Halliday, R.S.; Huey, R.; Hart, W.E.; Belew, R.K.; Olson, A.J. Automated docking using a Lamarckian genetic algorithm and an empirical binding free energy function. J. Comput. Chem. 1998, 19, 1639-1662, https://doi.org/10.1002/(SICI)1096-987X(19981115)19:14<1639::AIDJCC10>3.0.CO;2-B.

32. Kryger, G.; Silman, I.; Sussman, J.L. Structure of acetylcholinesterase complexed with E2020 (Aricept $\left.{ }^{\circledR}\right)$ : implications for the design of new anti-Alzheimer drugs. Structure 1999, 7, 297-307., https://doi.org/10.1016/s0969-2126(99)80040-9.

33. Yan, R.; Zhang, Y.; Li, Y.; Xia, L.; Guo, Y.; Zhou, Q. Structural basis for the recognition of SARS-CoV-2 by full-length human ACE2. Science 2020, 367, 1444, https://doi.org/10.1126/science.abb2762.

34. Wan, Y.; Shang, J.; Graham, R.; Baric, R.S.; Li, F. Receptor Recognition by the Novel Coronavirus from Wuhan: an Analysis Based on Decade-Long Structural Studies of SARS Coronavirus. J. Virol. 2020, 94, e00127-00120, https://doi.org/10.1128/JVI.00127-20. 
35. Wang, Q.; Zhang, Y.; Wu, L.; Niu, S.; Song, C.; Zhang, Z.; Lu, G.; Qiao, C.; Hu, Y.; Yuen, K.-Y. Structural and functional basis of SARS-CoV-2 entry by using human ACE2. Cell 2020, 181, 894-904, https://doi.org/10.1016/j.cell.2020.03.045.

36. Lan, J.; Ge, J.; Yu, J.; Shan, S.; Zhou, H.; Fan, S.; Zhang, Q.; Shi, X.; Wang, Q.; Zhang, L.; Wang, X. Structure of the SARS-CoV-2 spike receptor-binding domain bound to the ACE2 receptor. Nature 2020, 581, 215-220, https://doi.org/10.1038/s41586-020-2180-5.

37. Muhammad, A,; Arfan, A,; Nuralifah,; Wa Ode, H,; Laode, K. In silico exploration for aldose reductase (AR) inhibitors, Letters in Applied NanoBioScience, $\quad \mathbf{2 0 2 0}, \quad 9, \quad 956-960$, https://doi.org/10.33263/LIANBS92.956960. 